\title{
The Occupied City as a Sociological Laboratory: Developing and Applying Social Psychology in Warsaw I939-I945
}

Journal of Urban History 2017, Vol. 43(4) 587-60I

(c) The Author(s) 2017

Reprints and permissions: sagepub.com/journalsPermissions.nav DOI: $10.1177 / 0096144217705332$ journals.sagepub.com/home/juh

$\Theta$ SAGE

\section{Friedrich Cain'}

\begin{abstract}
The article explores the sociopsychological considerations made by Polish sociologist Stanisław Ossowski (1897-1963) during World War II in reaction to his specific experiences in Sovietoccupied Lwów and German-occupied Warsaw. Based on readings of Ossowski's publications and so far unpublished archival material, the influences and practical consequences of permanently observed violations of ethical and moral boundaries in that "great sociological laboratory" of war and occupation shall be traced in the texts he wrote during that time. As a member of a group of engineers, town planners, and architects, Ossowski sketched various psycho- and sociotechnical means of controlling that should guarantee for a peaceful social existence of free individuals in a new Polish state. Particular attention will be directed to the specific difficulties of attaining, communicating, and distributing knowledge in the de facto doubled cities that developed along the lines of opposition between the occupying and the occupied.
\end{abstract}

\section{Keywords}

town planning, history of sociology, historical anthropology, Stanisław Ossowski, World War II, occupation, Warsaw

Defining a city one way or another, it is a certain special milieu in which people live, develop and in which social relations tie. We know, that this milieu exerts an immensely significant influence on the shaping of any living beings. It influences biological characteristics, health, intelligence, [and] character, if they are human beings. ${ }^{1}$

When Polish sociologist Stanisław Ossowski stated this in February 1942, he had come a long way from observing the "specific atmosphere of the contemporary big city" under variously altered conditions. From September 1, 1939 onward, Ossowski had lived under and suffered from German attacks on Poland and from October on looked for a way to dwell in the occupied country. Until the end of World War II in early 1945, he would experience uncountable scenes of highly puzzling behavior of people roaming in occupied Warsaw that he only later could explain to himself. Upon a close cooperation with several architects and city planners during the war, Ossowski finally developed a theory of the human condition integrating his observations. The

IUniversity of Konstanz, Konstanz, Germany

\section{Corresponding Author:}

Friedrich Cain, University of Konstanz, Fach 213, 78457 Konstanz, Germany.

Email: friedrich.cain@uni-konstanz.de 
theoretical attempt to place the irrational and hardly explainable behavior observed within the confusing and then to large extent destroyed modern city emerged around the meetings of different academic disciplines and professions. That heterogeneous group met to tackle the contemporary building problems of the city as well as the expected challenges of the reconstruction of a free Polish state after the war.

The article examines the chiastic movement of (1) losing anthropological ground and thus struggling to explain the seemingly unexplainable as well as (2) trying to take the architectural design of space as a basis for building a just society based on that explanation. Both the explanatory attempt and the planning activities cannot be separated, though they have been described along different lines, so far. ${ }^{3}$ Therefore, the practice of theorizing human nature shall be recollected within the contemporary context of an emerging city whose hardly controllable development was brutally stopped and rearranged in September 1939. Depending on either passive or pragmatic narrative, this could lead to doubts in human nature and its milieu, or open up a short window of time to reconsider anthropological thought and feed this into sociology and planning. Either way, Ossowski's reflections about past and current needs of city planning made him formulate concepts on how to develop measures which he thought would help to tackle the problems of interwar Warsaw, now intermingling with the material, social, and psychic effects of occupation. Placing human psyche's development right in midst of the city with its economical and traffic factors he aimed to initiate nothing less than the "humanization of culture and care about man and social groups."

\section{Despair and Curiosity: Observation in Occupied Cities}

When German forces attacked Poland at the outbreak of World War II on September 1, 1939, everyday lives of Polish citizens changed fundamentally. However, war had become palpable beforehand in every part of social life. By the end of August, the capital was even more busy than usual, with travelers returning from summer leaves and soldiers being called to arms according to the general mobilization plan. As the outbreak of war seemed only a matter of time, large parts of society prepared for potential leaving, and after the German attack from the West and the Soviet invasion from the East following on September 17, tremendous masses eventually set out to reach places they felt safe at. The government fled southward, and via Romania reached Paris and Angers in early October from where it later moved to London. When the authorities of Warsaw surrendered to the German army on September 28, a period of skirmishing and besieging came to an end, which had brought severe damage not only to the Polish towns but also to the psychic and social life finally-war became occupation. ${ }^{5}$

While the "Reich" annexed large parts of Western Poland on October 26, Eastern territories were annexed by the Soviet Union in early November. In Central and Southern Poland, an area also controlled by German troops, the so-called Generalgouvernement was founded with Cracow as the capital and Warsaw as one of four (and later five) districts. This area was controlled by a German administration introducing harsh rules, which aimed to suppress any cultural, economic, or social life. Forced labor was introduced, uncountable workers were shipped to the "Reich," and from 1940 on, Jews were forced into ghettoes and later sent to extermination camps.

The new order forced Polish society to reorganize life. New administrative systems were introduced, public institutions closed or germanized, the distribution of food and other goods was limited and rearranged, and the pursuit of various professions was restricted or completely banned. The regime change led to consequences even in the most remote areas of prewar life, which can be traced in the multitude of contemporary reports or diaries. Depending on social status, knowledge, literary experience, interest, or spare time, the accounts and viewpoints differ widely. Descriptions run from skeletal sketches to lengthy accounts on food price developments, the demolition of economic and cultural goods up to private or psychic effects of the hostile 
intrusion. While most accounts were kept on an irregular basis, some chroniclers demanded to gain an overall view of society under occupation. ${ }^{6}$

Apart from alterations in length or detail between different accounts, there is one further quality that helps to classify these reports. It is a certain "socioscientific gaze" that stands out in some texts. It shall be understood as a specific way of looking at society with an informed interest in social structures and their interplay with environmental and individual phenomena. These texts do neither have a certain shape, nor do they necessarily follow genre or present first sketches of later publications. A certain claim for systematic approach is inherent and yet can these portrayals be fragmentary. That gaze is a mode of looking at social life while spotting and capturing certain relational aspects of the observed phenomena. It is too vague a term for calling it a proper method, and might rather stand alongside heuristic guidelines steering a first contact with new material. Finally, it is not a gaze knowing what it is looking for but rather a yet unstructured approach to observation. $^{7}$

Among the many gazers, here the Polish sociologist Stanisław Ossowski (1897-1963) shall be the example to follow. Ossowski compiled a rich collection of socioscientific observations during these years, which he spent as an officer of the Polish army, a refugee in Soviet-occupied Lwów, and a member of the resistance movement upon his return to Warsaw in autumn 1941. In his accounts, blurred and unexpected lines of narrative do occur. Rather than describing occupation as a total crisis of nation, state, or person, he would fill his diary entries, letters, notes and later manuscripts with observations of yet another set of social and psychic interdependencies with its own right to examination.

Writing about the future of Polish sociology shortly after the war, Ossowski stated, that "in the course of six years before our very eyes gigantic experiments on people and communities were conducted." During these "most cautious operations on human organisms, on human psyche, on communities and cultures," social bonds, group structures, and milieus were manipulated on a great scale. "The most artificial conditions of life" were impeded while no single means of "individual or collective conditioning" proved cruel enough to stop at. ${ }^{8}$ Ossowski went on to twist the brutality and despotism of occupation regimes into a unique and singular database that cannotor must not-be replicated. This would make it possible (and necessary) to analyze the data stemming from nonscientific Nazi operations "ex post in a way as if they had been implemented with scientific intent" on a large scale in the "sociological laboratory" which is human society. ${ }^{9}$ Elsewhere Ossowski added that the oddities observed in everyday life during the social situation of war and occupation were by no means abnormal but rather specific qualities of the human condition which cannot be seen in times of peace too often. ${ }^{10}$

Throughout the war, Ossowski gathered a wide range of "field notes," which he archived meticulously. Without keeping a regular diary, he piled up a vast collection of notes on important events of his personal life and social, political, or military events. In a period of distress and despair during the summer of 1940, he decided to "... return to scientific notes, even if the chance that I would use them again does not rise; in particular I concluded to keep a notebook on books I read and for loose reflections ..." ${ }^{11}$ By the time, many of these notes started to correspond with texts he sketched in later periods of the war. Observations from different social situations, readings, thoughts, and so on mixed and intermingled. This bundle of observations flows out of the specific habit of looking at society with socioscientific interest. Ossowski's gaze covered the places he visited and situations he observed all the time, making him note the rapid and fundamental changes. Fleeing to the areas occupied by Soviet troops, Ossowski found the town of Białystok full of red flags and banners, though Polish was spoken all over. Whereas many cafés were crowded by Warsaw bourgeois bohemia, the general atmosphere seemed rather provincial. ${ }^{12}$ Lwów, though also under Soviet reign, made a general "bourgeois" and "capital impression," 13 and when German troops invaded the city in July 1941, the rapid switch from fear to relief and praise fascinated and at the same time puzzled the observer, leaving an uncanny feeling concerning the human condition. ${ }^{14}$ 
Such scenes of parallel or mixing existence of incommensurable postures were noted down in awe or surprise by Ossowski. A great number of his "field notes" eventually made way into further considerations. The great range of disparate attitudes in single persons or groups must have seemed so interesting, that he started to take more and more interest in the structure of "human nature" 15 and came to describe a "multiplicity or polymorphicity of human psyche." 16 Abstracting from his observations, Ossowski developed several shorter tentative sketches from his readings and thoughts that came to be more and more concise. Writing down the many puzzling occurrences in different text types for several times, he began making sense of what happened in the realm of occupied cities. Explicitly disciplining his body and mind by scholarly techniques of reading, noting, and "concentrating on paper," 17 Ossowski let roam a usual socioscientific gaze in unusual conditions. Simultaneously, he widened the scope for new reflections within a field pervaded by that habitualized way of seeing that he would call a "sociological laboratory" later.

\section{Sociopsychological Investigations of the Doubled Urban Chaos}

Upon his return to Warsaw in 1941, Ossowski was active in various groups of the underground movement. ${ }^{18}$ Apart from secret teaching at the clandestine university which had developed after the ban of any activity considered cultural by the occupants, he was closely connected to a group of architects and city planners. As a part of an officially functioning housing cooperative that group worked out plans for the reconstruction of the parts of Warsaw destroyed under siege in 1939. This Studio for Architecture and City Planning (Pracownia Architektoniczno-Urbanistyczna [PAU]) was founded by several eminent architects, among them Stanisław and Barbara Brukalska or Helena and Szymon Syrkus, the latter of them being a co-author of the widely acknowledged study "Functional Warsaw" which was presented to the Congrès Internationaux d'Architecture Moderne (CIAM) during the Interwar period. ${ }^{19}$ It was probably the future president of the city, Stanisław Tołwiński, who made contact with Ossowski to employ him for his sociological expertise. Right after the siege, members of the Warsaw Housing Cooperative (Warszawska Spółdzielnia Mieszkaniowa [WSM]) were in charge of marking down damages and securing harmed buildings. Together with the Communal Building Company (Społeczne Przedsiębiorstwo Budowlane [SPB]) which had not been forbidden as well and with which the WSM had been cooperating before, the employed architects were responsible for two housing colonies in the boroughs of Żoliborz and Rakowiec. ${ }^{20}$

Working with this group in that specific context had a tremendous influence on Ossowski's work and thoughts on the polymorphicity of human psyche. A 1943 text published only in 1958 as a "historical record from those days" 21 starts off with an evening stroll through the occupied capital: "If we walk the dark streets of Warsaw in the evening and raise our eyes something reveals itself to us that before the war was not easy to spot . . . the dark sky and sparkling stars."22 Where the light of neon lamps had reduced the number of visible stars until 1939, destruction and brownouts opened up the firmament again during the war, as Ossowski went on in a somewhat dreamy tone. Dwelling in midst of a dark city, which had only four years ago been as bright as day even at night time, ruptured basic feelings of time and progress. ${ }^{23}$ The atmosphere of war and occupation had influenced the sense of time, namely, the lack of any personal measurement of time going by. That, as Ossowski wrote, led to an indefinite life without any planning of week, month, or year. It was a state of endurance without aims, "beyond time," against the fact that so much kept changing. ${ }^{24}$ Changes to the sense of time and space when the restraints of modernity broke away, or more exactly, without the schedules and schemes of the modern city, had been a topic in Ossowski's notes from the first weeks of the war. ${ }^{25}$

At the point where life in the anyway chaotic modern city had lost orientation, Ossowski started linking his idea of the "polimorphicity of human psyche" to his reading of the city-space. Conceptualizing the new regime not as another ensemble of laws and orders but as a thorough 
social and economic upheaval, he described the city as spatially partitioned not only into German, Polish, and Jewish districts but also into horizontal social spheres that each had their own written and unwritten laws. Next to the "official" rules introduced by the Germans, the extremely broad and well-organized Polish underground movement had developed codes of conduct, which were published in clandestine brochures and leaflets. ${ }^{26}$ However, as big and authoritative central organs of the so-called "Underground State" might have been at times, there were always minor groups with other ideological backgrounds that fought and published for other aims. ${ }^{27}$ Apart from that, some groups and individuals neither attached to the first nor the second set of rules but established their own conduct of life between the layers of legitimacy, serving several of them at a time depending on their personal benefit. ${ }^{28}$

Contingency had broken into daily lives neither assuring nor even suggesting any sure scenario for the end of the day. "One lives in midst of all imaginable opportunities," 29 as Ossowski put it. Whereas he played down changes of common value judgments even in the most strictly controlled societies, Ossowski described the loss of social control or else the multiplication of controlling structures as developing centrifugal dynamics to people's behavior, transgressing any earlier boundaries. The use of psychological language refers to the laboratory character of the social situation of war and occupation. If a "social group is torn apart from its normal condition, if its long standing habits stop functioning and the old, simple moral criteria lose their automatic application." ${ }^{30}$ The individual reactions offered vast material to examine the different and often unexpected reactions of individuals and groups:

The experiences from war years are very rich from this point of view. One could see how honest heroic enthusiasm gave way to despicable cowardice. One could see people that combined the most brutal obnoxiousness with solicitousness for friends, family, children . . . One could see people who otherwise were sensitive for the misfortunes of others, who sympathised ... and nearly imposed help; one could see these people indifferently taking news about most brutal maltreatments of defenceless citizens. ${ }^{31}$

The descriptions end with a hopeful application of the concept of human personality's "polymorphicity" that was born from the cruelties Ossowski had spotted in the occupied country: "the same human being can be so and so." 32 Switching to a genetic metaphor, he continues conceptualizing an "interplay of capabilities" that fosters or repels different attitudes "dominant" or "recessive." ${ }^{3}$ This switch however paved way for new anthropological thought and new ways of educating mankind that were rather pragmatist than utopian. Hope was there if the contingency of human psyche offered not only bad but also good elements. Based on the idea of polymorphism, Ossowski proposed to create environments in which to lock the possible capabilities in the respective population:

It is a question of how to compose conditions that would extract hidden capabilities from human beings and provoke a turn within the structure of their psyche; how to compose a system of radiation that causes a shift of the crystallisation axis in our personalities. ${ }^{34}$

Composing these conditions was a matter of urban planning. It is not by chance, that the text starts with a picture of a dark occupied Warsaw and that the further lain out problems build up on that first scene. The puzzling scenes described in his diaries, his work at PAU from autumn 1941 on, the general sociological background, and the socioscientific gaze all together influenced each other. In early 1945, while staying in Southern Polish countryside where he had retreated to before the outbreak of the Warsaw Uprising, Ossowski wrote a lengthy text on the social demands of the reconstruction of the country's capital. There he listed six psychological changes that especially the youngest generation of Varsovians had suffered from since 1939. Occupation had torn down feelings of boundaries in people inhabiting an environment quasi not regulated by law. 
Acts which would have been punished before 1939 passed with impunity. The abandonment and often vital transgression of old norms led to general impairment of moral sensitivity. Furthermore, general spite for occupational administration fostered disobedience to any authorities, and a vacuum between the expected breakdown of the German and the introduction of a new Polish administration might reinforce that. Especially the younger generation, which had not been educated morally for six years at an important stage of development, would need much attention. ${ }^{35}$ Taking this as a summary of his observations and taking into consideration the anthropological switch to a polymorph psyche, that list stands out as an attempt to integrate the field of planning into the sociological laboratory of the occupied city.

\section{Translating Sociology into Urban Planning}

In early 1940 it turned out that the German occupants would not close the $S P B$ but let it work under special conditions. The now official status offered a way to provide architects and activists with work as well as the important identity cards often preventing arbitrary incarceration. With more commissions for restoration or installations coming in, the company's potential grew quickly. Here many specialists for housing, supplies, and new building methods could meet on the background of earlier contacts. In September 1941 these activities were united under the name of Studio for Architecture and City Planning that had been acknowledged by the occupant authorities as an organ of the SPB. ${ }^{36}$ Apart from actual construction works, this group went on to reattach to the ideas developed before 1939, especially in the working group Praesens that had been in close contact to CIAM. In fact, these plans foresaw a functional design for the city within its region, planned not in individual but collective work and following a new method of "Urbanistics." What had been probed mostly in the two boroughs of Żoliborz and Rakowiec so far was to be transposed to the whole city and its different functional parts.

Doing that, the architects tried to transgress the borders of their discipline. While there had been a tradition to cooperate with the administrative staff of the estates in readjusting details of their design, in autumn 1941 they set out for a programmatic extension and to introduce a close and steady cooperation with geographers, economists, and sociologists for planning the whole city. ${ }^{37}$ Without rejecting the studies on "Functional Warsaw" from the 1930s and the focus on communication and spatial relations of working and living districts, society as an ensemble of human individuals gained an important role. Written in October 1941, the proposal to introduce a sociologist to the PAU begins as follows:

When chaotic private construction gives way to planned action in building guided by social factors, and the architect's work gets inseparably linked to the city planner's new aspects and concepts have to play a role in projecting an estate: the realm of planning transgresses bricks, iron and concrete and has to take into consideration human organisms and forms of social life. ${ }^{38}$

The text goes on with a critique of profitability or comfort as insular main goals of private construction that would have to be replaced by society as the center of building initiatives. Finally, the tasks of sociological experts are lined out, among them an introduction to ecology. The latter was framed as the study of the specific interplay of societies, cultures, and their environments, that should develop guidelines to influence these interdependencies for architects and city planners. Furthermore, multistage social systems and the horizontal and vertical connections between flats, colonies, boroughs, towns, and regions should be analyzed and provided with socalled "radiating institutions" fostering social bonds. Finally, urban planning was to be connected to questions of social and political systems. ${ }^{39}$

It is not by chance, that it was occupied Warsaw where this proposal was written. War remained silent in the text, whereas the rampant process of Warsaw's urbanization that seemed hardly 
controllable and even less reversible was much more present. Although the activities of the Praesens group had been widely known in expert circles, their factual implementation had never been completed. Apart from scattered parts of town, large scaled plans had not been tackled so far. In fact, these plans had so far only been reactions to the chaotic outlook of the city. ${ }^{40}$ Although barring many other ways to act, war now at least offered the time - and with the demolitions even space - to plan the city: not from the scratch, but with much more freedom to intervene in the destroyed cityscape. As the emergence of modern Warsaw fell into a period of political dependence to the Russian empire and large-scale building plans fitting a free nation's capital had not been set into action. After 1918 the economic situation and factual existence of built structures made it impossible to complete large-scale projects. Ironically the much-mourned destruction starting in 1939 provided some commentators with hope for something like a second emergence of the city whose outcome would not fall to chance. At this point, architects, city planners, and sociologists got in touch and felt a real opportunity to create freely against the background of the social, political, and material catastrophe of war.

The districts that had been connected on the basis of functionalist analysis, but not internally scrutinized so far, were to be central to planning activities, now. The Studio introduced five groups in which the different boroughs should be analyzed focusing on social bonds. ${ }^{41}$ Each group had its own schedule. Once a month the group representatives met in plenary sessions to discuss different problems on a larger scale. ${ }^{42}$ It was in one of these latter meetings, that Stanisław Ossowski gave his first talk, taking up the lines of thought presented in the proposal trying to apply "scientific research" to the construction of buildings in a way that would simultaneously lead to the education of "new human types," the creation of "new forms of social life," and the production of a "new culture." 43

However, transfer of concepts or knowledge was never asymmetrical. From autumn 1941 on and through the course of the following three years, the concept papers, presentations, and discussions in the Studio underlay some sociological influence in language and content, indeed. Simultaneously, the flaneuresque text quoted above drew heavily from the cooperation when closing with the question of how to install a system that would help to create a new mankind. A longer manuscript on social psychology is also heavily influenced by these questions. ${ }^{44}$ Both fields of thought-city planning and social psychology-were strongly linked in time and space, though on a conceptual level they did only converge in the course of time. Whereas polymorph human psyche stemmed from socioscientific gazing at war's chaos, the attempted solution found its way into Ossowski's social psychology only after some time of observation, doubt, and trial. At the same time, the strong inclination toward social planning can be traced back to lively discussions from the Studio. In other words, the polymorph psyche was not an idea transmitted to city planning but a sociopsychological conceptualization of thoughts and drafts Ossowski came to take a closer look at during his work with the Studio.

The tasks set for the sociological expert were to present relevant literature from his discipline and make it accessible to the architects. Delivering a talk in November 1941, Ossowski outlined the intersections of planning and sociology, especially regarding their interdependencies in modern cities. Building his argument on two sociological traditions which he introduced as a functional analysis of cultural phenomena, attributed to Karl Marx, and Herbert Spencer's description of society as an organism, Ossowski proposed a methodological mix of both. From there he continued to formulate suggestions for the Studio's work that would take into consideration the connection between cities and their inhabitants. ${ }^{45}$ Planning should rely on empirical laws described in sociographic analysis and should take into account the functional significance of architectural forms inserted into specific cultural contexts. ${ }^{46}$ Hence, Ossowski pointed at the interconnectedness of planning activities, specifically mentioning the political system and the distribution of power as well as economical, aesthetical, or hygienic trends or ideas of social bonds and social systems. ${ }^{47}$ 
Upon Ossowski's talk, a discussion evolved around the impact sociology could make in planning processes. Several attendants underlined the importance of systematic cooperation on equal terms. Especially when it came to the design of blocks and estates or the infrastructural connection or dissociation of boroughs destined for life and work, sociological expertise was warmly welcomed. As one attendant remarked, earlier works had already included studies on inhabitants' contentment, though evaluation had only been carried out by architects themselves and not by social scientists. ${ }^{48}$ Another voice pointed out that not only sociological questions would be of interest but also other specialists such as economists, medical doctors, teachers, artists, suppliers, or administrators should be closely involved from the very beginning. Rather than pressing life into forms made up by architects, forms should be designed on the basis of insights into life. ${ }^{49}$ Especially predominant was the idea that "people of science" might shed light on facts, which were blurred in the eyes of architects with their "fetish-like" relation to their works. ${ }^{50}$

Next to sociological expertise, yet another motive stuck out of the discussion, namely, the part human beings played within the plans of cities. Ossowski's demand to take into account deliberate decisions of planners and builders or inhabitants when analyzing a city was widely agreed upon. One member dreamt of a time in which "human nature and social bonds" would be so well known to architects that the inhabitants' behavior within meticulously planned parts of town would not bear any major surprises..$^{51}$ Ossowski underlined a need to closely link scientific analysis and experienced architectural work. He also strongly insisted on the argument that city planning was a "special terrain, where scientific research becomes a part of the scrutinised reality, a creative factor itself", but inseparable from the sociopolitical ideas that planners, architects, and sociologists rely on. ${ }^{52}$

The human factor became even more prominent in other contributions of Ossowski's to the Studio. In early 1942, he specifically pointed at the frictions, which might occur in a functional city if social and cultural institutions existed twice in different parts of town. Multistaged systems would have to take into consideration not only the urban integrity of single boroughs but also the permeability of spatial and social borders within the city. This would also concern the social bonds, which would have to be planned cautiously to not underestimate the many different ways in which a feeling of solidarity might develop. ${ }^{53}$ Again some listeners applauded the important shift in planners' thinking, namely, the new central role of man, which had been giving way to questions of communication and economy for too long. ${ }^{54}$ These discussions in the studio deliver a picture of attempts to "translate" sociological knowledge into urban forms, as Ossowski put it once..$^{55}$

\section{Thinking Urban in Emerging Cities}

Against all astonishment provoked by the sociological thoughts in PAU, it remains to be determined whether this was a first encounter. It surely was an opportunity where contact was made, and interest, time, and problems to be solved were at hand. This not only counts for knowledge transfer from sociology to planning but also the other way around. Before shifting the one or the other to a higher level, here, triggering surprise, discussions, and reflections was central.

Heavily puzzled by and at the same time bearing on his observations of occupied Poland, and especially in its cities, Ossowski developed a way to explain the disparate and disturbing situations he kept spotting. Against his academic background, he found a way to explain certain traits in human behavior which he was no longer ready to play down as exceptional due to their ubiquity. Starting from a gaze at occupied society and himself, he tried to make sense of the chaos and to install sets of rules to organize his personal self, his emotional and sensual apparatus and then went on to find a way to describe human nature to make sociological ends meet. Socioscientific gazing had a double function here, as it shuttered all known explanations and at the same time made it possible to interpret observations not as decline and exception but as some social behavior worthy 
of interrogation. The sociological laboratory of occupied Warsaw produced different ways of conducting observations; these observations demanded sociological interpretation at the same time, which again started from socioscientific gazing that mediated and produced the field.

Desperation and interest worked together in this process, the former being an extreme version of surprise or amazement - a usual starting point for scientific investigation. With time at hand and the driving gaze, the concept of the polymorph human nature emerged which could integrate but still not solve many of the dreadful episodes and uncanny reactions observed. Alas, due to the theoretically informed description and explanation, doubts about mankind being basically good (or bad) were superseded by the idea of a highly fragmented human psyche never forming a monolithic entity. Furthermore, the genetic vocabulary describing recessive and dominant traits of character and their dependence on external factors did not fall to a fear of bad influence, but triggered optimism concerning opportunities to steer and design. Citing the same sociological and philosophical sources in both his sociopsychological texts and the contributions to the PAU, Ossowski assumingly had found one way to explain the chaos to himself (and his discipline) and to contribute to the solution of architectural problems. Dwelling, gazing, and working in the city merged and provided his personal situation with a deeply urban character.

On the other hand, the material, geographical, and financial obstacles inherent to practical planning were important points to attach sociological thought. Forced to leave something like the "natural cosmos" of sociology proper-how far that discipline had closed its borders yet is not to be decided here-Ossowski opened his work for the planners' lines and needs of thoughts. Having sacrificed any a priori optimism concerning human nature, he abandoned eschatological hopes for a revolution or messiah solving the miserable conditions. Instead, he turned to polymorph psyche and unconditionally linked a somewhat perfect future to present activism. That also found expression at the end of his sociopsychological works. Not history's power but innovative systems would produce the new mankind that was dreamt of. Instead of creating goals to achieve, a merciless analysis of the social situation should lay ground for tools to educate a new mankind whose countenance was not yet known. This human being was a statistical quantity of cultural quality, malleable to a great but not to utmost extent. All that came up in occupied Warsaw with its wrecked houses, ruins, and debris all around, triggering not only thoughts on projects officially commissioned but also wide conceptual studies regarding the whole city. War offered time and space for broader thinking, and made the Studio a highly productive intellectual space.

As indicated above, the new method of planning Warsaw was closely linked to considerations of sociological factors and thinking about these was demanded. Following this testimonial, Ossowski worked out several texts on factors identified as influential to social processes. Trying to redeem the sociological promise, he challenged urban problems from different posts. The hope he had derived from his concept of polymorphism also became a presupposition for some of his arguments in urban planning. To prevent dissocial behavior, Ossowski called for meshing a multistaged net of self-administrated institutions spanning the whole city and reaching the tiniest corners of any unit.

Human soul's polymorph structure was to be locked in an ethical position of responsibility for society as a whole. Therefore, a framework had to be built that would guarantee the grasp of Ossowski's polymorph human psyche. As it had already been a basic feature of the preceding works of PAU to group estates around ensembles of crèches, reading rooms, and certain housekeeping facilities, Ossowski's conceptual works intended a branched system — or net — of libraries and cultural institutions which should merge along so-called "axes of crystallisation" into larger "houses of culture." 56 These, however, were to offer a diverse program based on selforganization which would foster individual initiatives. Self-governance in the cultural field was so very important as it should help to school cooperative organization in further areas, for example (industrial) work and of course political democracy. ${ }^{57}$ The penetration of working districts 
with similar facilities, imperatively coordinated with housing districts' facilities, would offer a chance to loosen working conditions. The interplay of these measures should finally disperse the compulsory nature of labor. With the human being at the center of planning, work would lose its central position to man's attitude toward vocation. Only that would grant creativity to the average man, what became a doctrine of PAU.

The PAU did not remain the only example of city planning in occupied Warsaw. A group of former city officials, who had not been removed from their posts or moved to other branches, had vast municipal archives at their disposal. Among them were Jan Zachwatowicz and Jan Chmielewski, the latter of them also taking part in PAU meetings. Based on the official material, further plans for the city were worked out. Alas, the actual process cannot be retraced anymore, as the papers were either lost or forgotten. However, two surviving texts stemming from these efforts were published only in the $1980 \mathrm{~s}$ in historical journals. ${ }^{58}$ As most ideas from PAU, also these concepts did not find direct access into postwar city planning. Yet, some members of the group made their way into planning committees after 1945, especially to the Bureau for the Reconstruction of the Capital (Biuro Odbudowy Stolicy [BOS]). Next to clandestine efforts of Polish architects, also the German occupants had been making plans for the city, though with opposite intentions. Whereas the Poles kept planning a capital of a free state, the planners around Hubert Groß followed another lead. According to their plans, Warsaw, "Die neue deutsche Stadt [The new German City]," was to be home to 120,000 German inhabitants and should serve the purposes of a provincial town not reminding of a Polish nation. ${ }^{59}$ For all these planning activities, the existing structures were at least unfavorable, and at worst subject to destruction. When German troops annihilated the city after the Warsaw Uprising in 1944 some Polish architects even went so far to- somewhat ironically-take the annihilation of the city as a chance for their wide ranging planning activities, "again." 60

Though a "tabula rasa" had never been part of conceptions at PAU, war was welcomed as a break for individualized private building, and planning at a larger scale took of on a highly organized level in the Studio. However, instead of a provincial town as thought of by the Nazis or the radical new building concept of Zachwatowicz's and Chmielewski's, the PAU minutely worked out a redesign of structures that would be grounded on the cooperation of not only planners and architects but also the inhabitants themselves. As Ossowski once put it, architects should not take influence as of their professional expertise, but rather as citizens of a state. ${ }^{61}$ Retelling the German urbicide not as catastrophe but as opportunity and roaming the city with a socioscientific gaze helped to frame the inhabitants' dissocial behaviour as an all too human polymorphicity, opening intellectual capacities for yet another emergence of Warsaw.

The PAU activities are an example of the inseparability of thought and world, or rather the crude interplay of seeing and making sense of the observed to stabilize persona, personal and academic discipline, and, at times, society. Ossowski, having recognized and adjusted modern urbanity as a factor central to his sociopsychological puzzle, was able to reframe his observations as a sample recorded in a laboratory as he called it after the war. Getting in touch with the PAU, the Urban received a doubled connotation of problem and solution at once. Looking at the decline of morals against the background of socioscientific gazing, a specific complex of knowledge about human condition arose that poured down into the concepts, which should dissolve the social problems of war-and peace.

\section{Author's Note}

The author is responsible for all translations from Polish texts. 


\section{Acknowledgments}

The author thanks Róża Sułek for her help in finding and interpreting several documents and Florian D. Ernst for advice in language issues.

\section{Declaration of Conflicting Interests}

The author declared no potential conflicts of interest with respect to the research, authorship, and/or publication of this article.

\section{Funding}

The author disclosed receipt of the following financial support for the research, authorship, and/or publication of this article: The article is part of a larger research project on the works of Polish scientists under German occupation during Word War II. The PhD-project is based at the University of Konstanz (Germany) and funded by the Cluster of Excellence 16 "Cultural Foundations of Social Integration" funded by DFG (German Research Foundation).

\section{Notes}

1. Stanisław Ossowski, "Socjologiczne podstawy nowoczesnej urbanistyki [Sociological Foundations of Modern Urban Planning, 1942]," Archiwum Polskiej Akademii Nauk w Warszawie [APAN-W], III-185, box 104, 10-26: 11.

2. Stanisław Ossowski, "Organizacja przestrzeni i życie społeczne w przyszłych osiedlach [Organizing Space and Social Life in Future Housing Estates, 1942]," APAN-W, III-185, box 97, 48-81. The text was published posthumously in the 3rd volume of Ossowski's collected works: Stanistaw Ossowski, Dzieła t. III [Works Vol. III] (Warszawa: Państwowe Wydawnictwo Naukowe, 1967), 351-70: 358.

3. Though texts on both activities were published in the third of six volumes containing Ossowski's collected works, literature has not described these close links. See Jakub Karpiński, "Ossowskiego Psychologia Społeczna [Ossowski's Social Psychology]," Więź 17 (1974): 59-73 or Mirosław Chałubiński, "The Sociological Ideas of Stanisław Ossowski: His Life, Fundamental Ideas and Sociology in Polish and World Science," Journal of Classical Sociology 6 (2006): 283-309.

4. Ossowski, "Socjologiczne podstawy," 24.

5. Out of many accounts from the city of Warsaw, see, for example, the three volumes of Ludwik Landau, Kronika lat wojny i okupacji [Chronicles of the Years of War and Occupation] (Warszawa: Państwowe Wydawnictwo Naukowe, 1962-1963), or Witold Kula, Dziennik czasu okupacji [Diaries from the Times of Occupation] (Warszawa: Państwowe Instytut Wydawnicze, 1994). For historiographical descriptions, see, for example, Jürgen Matthäus, Jochen Böhler, and Klaus-Michael Mallmann, War, Pacification, and Mass Murder, 1939: The Einsatzgruppen in Poland (Lanham: Rowman \& Littlefield: 2014) and still Tomasz Szarota, Okupowanej Warszawy Dzień Powszedni [Everyday Life in Occupied Warsaw] (Warszawa: Czytelnik, 1988).

6. For Warsaw, see again Landau, Kronika. The Jewish Ghetto was described by Emanuel Ringelblum, Notes from the Warsaw Ghetto: The Journal of Emmanuel Ringelblum, ed. and trans. Jacob Sloan (New York: McGraw-Hill, 1958).

7. It was only after finishing this text that I received note of Per Wisselgren's book. The Social Scientific Gaze. The Social Question and the Rise of Academic Social Science in Sweden (Farnham, Burlington: Ashgate, 2015). However, Wisselgren has a different case study and defines the Social Scientific Gaze in another way. Calling that gaze "socio-scientific" rather than "sociological" is to prevent an all too early exclusion of anything that might not pass as the latter and rather fit into neighboring disciplines. Not only in Poland had the academic discipline of sociology gained a considerable status in the late 1930s but also it was still not as widely acknowledged as in later years after its restauration in the late 1950s. Therefore, the socioscientific gaze as it is used here is neither restricted to certain academic disciplines nor authors. To put it in the contemporary terms of Ludwik Fleck and his description of medical disciplines, it is still about looking and not yet seeing, but it is about a way of looking that is being informed backward, from a certain way of seeing: Ludwik Fleck, "To Look, to See, to Know [1947]," in Cognition and Fact: Materials on Ludwik Fleck, ed. Robert S. Cohen and Thomas Schnelle 
(Dordrecht, Boston, Lancaster, Tokyo: D. Reidel, 1986), 129-51. See also the interesting contemporary critique of "calling everything sociology" by Tadeusz Szczurkiewicz, "Moda na socjologie [The Fashion of Sociology]," Ruch IV (1937): 557-75 and Nina Kraśko, Instytucjonalizacja socjologii w Polsce 1920-1970 [The Institutionalization of Sociology in Poland 1920-1970] (Warszawa: Wydawnictwo Naukowe PWN, 1996).

8. Stanisław Ossowski, "Socjologia w świecie powojennym [Sociology in the Postwar World, 1946]," in Stanisław Ossowski, Dzieła t. VI (Warszawa: Państwowe Wydawnictwo Naukowe, 1970), 164-74: 168.

9. Ossowski, “Socjologia w świecie powojennym," 168.

10. To describe the switches of human conduct, Ossowski introduced a genetic or evolutional terminology into his sociopsychological works. He modified the evolutionary, however, in eliminating any normativity, and introducing possible revisions to diachronic developments. See Stanisław Ossowski, "Nauki humanistyczne a ideologia społeczna [The Humanities and Social Ideology]," Nauka Polska 22 (1937): 1-24 and Stanisław Ossowski, Więź społeczna i dziedzictwo krwi (Warszawa, Poznań: Polski Instytut Socjologiczny, 1939).

11. Stanisław Ossowski, "Dzienniki, t. 9 [Diaries, Vol. 9]," Połaczone Biblioteki WFiS UW, IFiS PAN $i$ PTF [Pot. Bib. UW/PAN] (June 29, 1940), Rkp. 339, 391.

12. Stanisław Ossowski, "Dzienniki, t. 7 [Diaries, Vol. 7]," Pot. Bib. UW/PAN (November 29, 1939), 217-19.

13. Stanisław Ossowski, "Dzienniki, t. 7 [Diaries, Vol. 7]," Pot. Bib. UW/PAN (December 11, 1939), 229.

14. Stanisław Ossowski, "Dzienniki, t. 8 [Diaries, Vol. 8],"Pot. Bib. UW/PAN (June 30, 1941), 332-34.

15. Maria Ossowska and Stanisław Ossowski, Intymny Portret Uczonych. Korespondencja Marii $i$ Stanistawa Ossowskich [Two Scholars' Intimate Portrait. The Correspondence of Maria Ossowska and Stanisław Ossowski], ed. Elżbieta Neyman (Warszawa: Sic!, 2002), 347 (January 4, 1941).

16. Ibid., 372-73 (March 16, 1941). Without quoting Freud directly, Ossowski most likely derived that term from his works. See, for example, Sigmund Freud, "Drei Abhandlungen zur Sexualtheorie [Three Essays on the Theory of Sexuality, 1904]," in Gesammelte Werke. Werke aus den Jahren 1904-1905 [Collected Works. Works from the Years 1904-1905], ed. Anna Freud e.a. (Frankfurt/Main: Fischer 1999), 27-159: 91. Both Maria and Stanisław Ossowski read Freud's texts. See Ossowska and Ossowski, Intymny Portret Uczonych, 317, 320 (July 30, 1941, August 15, 1941) as well as Stanisław Ossowski, "Materiały warsztatowe II (z czasów 20-lecia międzywojennego i II wojny światowej) [Working Material II (from the Interwar Period and World War II)]," Pot. Bib. UW/PAN, Rkp. 385: 190-98.

17. Stanisław Ossowski, "Dzienniki, t. 8 [Diaries, Vol. 8],"Pot. Bib. UW/PAN (June 29, 1940), 301.

18. Ossowski taught at both clandestine universities in Warsaw, that is, the Secret University of the Western Lands (Tajny Uniwersytet Ziem Zachodnich [TNZZ]) and Warsaw University. Moreover, he worked in several cells of the exiled government's secret representation. He also maintained contact with further groups from the leftist milieu. See, for example (though not exhaustive), "Materiały ankietowe dot. działalności tajnego U.W. w czasie okupacji [Material on the Proceedings of the Secret University of Warsaw During Occupation]," Dział Rękopisów Biblioteki Uniwersytetu Warszawskiego, 2203, folder 2: 133 .

19. Jan Chmielewski and Szymon Syrkus, Warszawa Funkcjonalna. Przyczynek do urbanizacji regionu warszawskiego [Functional Warsaw. A Contribution to the Urbanization of the Warsaw Region] (Warszawa: Towarzystwo Urbanistów Polskich, 1934).

20. See Helena Syrkus, Ku idei osiedla społecznego 1925-1975 [Towards the Idea of a Social Housing Estate 1925-1975] (Warszawa: Państwowe Wydawnictwo Naukowe, 1976), 229-23.

21. Stanisław Ossowski, "Z $Z$ nastrojów manichejskich [On Manichean Moods, 1943]," in Stanistaw Ossowski, Dzieła t. III (Warszawa: Państwowe Wydawnictwo Naukowe, 1967), 189-97: 189. The manuscript is stored in Pot. Bib. UW/PAN, Rkp. 354: 34-45.

22. Ossowski, "Z nastrojów," 189.

23. Ibid., 189-90.

24. Ibid., 190.

25. Stanisław Ossowski, "Socjolog na wojnie. Dziennik wojenny z września 1939 [A Sociologist at War. War Diaries from September 1939]," in Kultura i Społeczeństwo 2 (1989): 133-49: 136. 
26. See, for example, Piotr Majewski, comp., "Instrukcje Walki Cywilnej," in Dokumenty i Materiaty Archiwum Polski Podziemniej 1939-1956, nr. 3, ed. Dariusz Baliszewski, Andrzej Chmielarz, Jan Kreusch and Andrzej Krzysztof Kunert (Warszawa: Kopia, 1995), 89-109.

27. See Jan Karski, Story of a Secret State (Boston: Houghton Mifflin Company, 1944) and Stefan Korboński, The Polish Underground State: A Guide to the Underground, 1939-1945 (New York: Columbia University Press, 1978).

28. See, for example, the classic description of Jan Tomasz Gross, Polish Society under German Occupation: The Generalgouvernement, 1939-1944 (Princeton: Princeton University Press, 1979), especially chapter "X. The Underground as a Social Movement."

29. Ossowski, "Z nastrojów," 191.

30. Ibid., 195.

31. Ibid. In the passage following directly after the description of people seemingly acting in an inconsistent manner toward neighbors and foreigners, the picture is painted even stronger. If indifference might be a mechanism of self-protection on one hand, there is yet another quality to it that stood out: sometimes it was reported that people more or less openly applauded cruelties and murder if the victims were exclusively Jews instead of protesting or keeping quiet. The passage closes as follows: "News came from detention camps that an inmate who had been made warder ... often behaved more dreadfully ... than normal wardens who had never been prisoners themselves" (195-96).

32. Ibid., 196.

33. Stanisław Ossowski, "Z zagadnień psychologii społecznej [On Questions of Social Psychology, 1943]," in Stanisław Ossowski, Dzieła t. III (Warszawa: Państwowe Wydawnictwo Naukowe, 1967), 9-185: 110.

34. Ossowski, "Z nastrojów," 197.

35. Stanisław Ossowski, "Odbudowa stolicy w świetle zagadnień społecznych [Social Questions of the Reconstruction of the Capital, 1945]," in Stanistaw Ossowski, Dzieła t. III (Warszawa: Państwowe Wydawnictwo Naukowe, 1967), 391-15, 404-405.

36. See Syrkus, Ku idei, 229-39.

37. "I zebranie w Pracowni Architektonicznej i Urbanistycznej SPB z odczytem p. Prof. S. Ossowskiego dnia 20 listopada 1941 roku [ $1^{\text {st }}$ Meeting in the Studio for Architecture and City Planning With a Lecture by S. Ossowski]," Pot. Bib. UW/PAN, Rkp. 359, 37-71: 61.

38. Stanisław Ossowski, "Projekt zamówienia na prace socjologiczne dla Pracowni ArchitektonicznoUrbanistycznej [Plan for Commissioning Sociological Works for the Studio for Architecture and City Planning, 1941]," APAN-W, III-185, box 86, 25-30: 25. Partly published in Syrkus, Ku idei, 307-308.

39. Ibid., 28-29. See also Syrkus, $K u$ idei, 307-308. The paper further sketched a series of presentation on "American ecological literature," for example, Mumford's "Technics and Civilisation" or "The Culture of Cities" (27).

40. For a prewar history, see the account in Martin Kohlrausch, "Warszawa Funkcjonalna: Radical Urbanism and the International Discourse on Planning in the Interwar Period," in Races to Modernity: Metropolitan Aspirations in Eastern Europe, 1890-1940, ed. Jan C. Behrends and Martin Kohlrausch (Budapest, New York: Central European University Press, 2014): 205-31, 208-15.

41. Syrkus, $K u$ idei, 237-38. These five groups should work on (1) the city and region of Warsaw as a whole, (2) the Northern residential areas, the extension of the colonies of (3) Żoliborz, and (4) Rakowiec as well as (5) a conceptual study of an industrial quarter in the Western parts of town.

42. Syrkus, $K u$ idei, 238-39.

43. "I zebranie," 37-73. The text also was published with minimal changes in the 3rd volume of Ossowski's collected works: Stanisław Ossowski, "Urbanistyka i Socjologia [Urban Planning and Sociology, 1941]," in Stanistaw Ossowski, Dzieła t. III (Warszawa: Państwowe Wydawnictwo Naukowe, 1967), 337-49. See also Syrkus, Ku idei, 241-42 for contextualization. As with a decision by the group, the talks and protocols of discussions had to be printed, duplicated, and kept in the Studio's library for further use. Usually the texts were typewritten and bound together with reports from the discussions. The files were provided with signatures indicating thematic affiliation, and stored in the libraries for all members of the SPB to use. See, for example, Stanisław Ossowski, "Ogólne zagadnienia dotyczące współżycia zbiorowego w dzielnicy pracy [General Questions on the Social Life in the Districts of Work, 1943]," $A P A N-W$, III-185, box 97, 24-47 or "Alfabetyczny spis książek biblioteki S.P.B. 
[Alphabetic List of the Books in the SPB-Library]," $A P A N-W$, III-185, box 94, 62-97. This was to guarantee the proliferation of the "new method" that the Studio's founders were keen to establish. As the discussion following Ossowski's presentation was not published in the collected works of Ossowski, only the actual presentation is cited from there.

44. Ossowski, "Z zagadnień," 9-185.

45. Ibid., 338 .

46. Ossowski, "Urbanistyka," 334. Here, Ossowski turned unspecifically to the writings of E. W. Burgess and his structural analyses of cities' anatomies that had literally placed the different quarters and their inhabitants in relation to each other.

47. Ibid., 344-48.

48. "I zebranie," 66-67. See also Martin Kohlrausch, “'Houses of Glass.' Modern Architecture and the Idea of Community in Poland, 1925-1944," in Making a New World: Architectures \& Communities in Interwar Europe, ed. Rajesh Heynickx and Tom Avermaete (Leuven: Leuven University Press, 2012), 93-103.

49. "I zebranie," 67-68.

50. Ibid., 60 .

51. Ibid., 61-65.

52. Ibid., 70-71.

53. "Protokół zebrania z dnia 19.II.1942 r. współpracowników PAU [Protocol of the Meeting at the Studio for Architecture and City Planning on 19 February 1942]," APAN-W, III-185, box 84, 55-62: 56-57. The text was published in Syrkus, Ku idei, 309-302.

54. "Protokół," 3.

55. "Sprawozdanie z prac P.A.U. w I kwartale 1943 roku [Report from the Works of the Studio for Architecture and City Planning in the $1^{\text {st }}$ Quarter of the Year 1943]," APAN-W, III-185, box 85, 64-0: 64.

56. See Ossowski, "Z nastrojów," $196-97$ as well as Ossowski, "Z zagadnień," 180 for the "axes" and the following for the houses Stanisław Ossowski, "Ogólne zagadnienia". The text was published with some changes as Stanisław Ossowski, "Ogólne zagadnienia dotyczące współżycia zbiorowego w dzielnicy pracy," in Stanisław Ossowski, Dzieła t. III (Warszawa: Państwowe Wydawnictwo Naukowe, 1967), 371-90. See also Syrkus, Ku idei, 313-19.

57. Stanisław Ossowski, "O drogach upowszechnienia kultury umysłowej na wyższym poziomie [On Spreading Intellectual Culture on a Higher Level, 1944]," in Stanisław Ossowski, Dzieła t. VI (Warszawa: Państwowe Wydawnictwo Naukowe, 1970), 144-57: 150, 153.

58. Jan Zachwatowicz, "Komisja Rzeczoznawców Urbanistycznych przy Zarządzie Miejskim Warszawy w latach 1939-1944 [The Expert Comission for City Planning at the City Council of Warsaw in the Years 1939-1944]," Rocznik Warszawski XVII (1984): 245-307 and Jan Zachwatowicz, "Uwagi Wydziału Planowania Miasta do opinii Komisji Rzeczocznawców Urbanistycznych z 1939-1940 roku [Comments of the City Planning Council on the Opinions of the Expert Comission for City Planning from 1939-1940]," Rocznik Warszawski XVIII (1985): 303-49. For an overview, see Helena Syrkus, Społeczne cele urbanizacji. Człowiek i środowisko [Social Goals of Urbanization. Man and Milieu] (Warszawa: Państwowe Wydawnictwo Naukowe, 1984): 367-75.

59. Niels Gutschow and Barbara Klain, Vernichtung und Utopie. Stadtplanung Warschau 1939-1945 [Annihilation and Utopia. City Planning in Warsaw 1939-1945] (Hamburg: Junius, 1994), 21-54. From 1942 on, Friedrich Pabst was in charge of German city planning. He did not further work on Groß's plans (103-8).

60. See, for example, Gutschow and Klain, Vernichtung und Utopie, 85. The original documents are not available in state archives, but still property to Chmielewski's descendants.

61. Stanisław Ossowski, "Zagadnienie organizacji życia społecznego w nowych osiedlach [The Question of the Organization of Social Life in New Housing Estates, 1942]," $A P A N-W$, III-185, box 97, 48-81: 78, also published as Stanisław Ossowski, "Organizacja przestrzeni i życie społeczne w przyszłych osiedlach [Organizing Space and Social Life in Future Housing Estates]," in Stanistaw Ossowski, Dzieła t. III (Warszawa: Państwowe Wydawnictwo Naukowe, 1967), 351-70, though without the sentence quoted. 


\section{Author Biography}

Friedrich Cain is a doctoral student at the University of Konstanz. He is currently finishing a dissertation on Polish scholars under German occupation during World War II, focusing on the social, material, and epistemic tactics and techniques necessary to organize research under the conditions of occupation. A second project focuses on interwar epistemology in Warsaw, 1918-1939. See Friedrich Cain and Bernhard Kleeberg (ed.), A New Organon. Science Studies in Interwar Poland (Tübingen: Mohr Siebeck, 2017, forthcoming). 